$20 p 3$

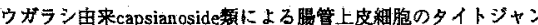

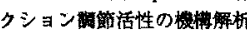

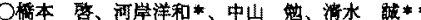

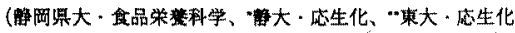

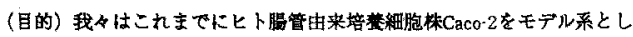
て用い、シシトウ水搜出物がタイトジャンクション们の物筫透過性を影 著に增大することを見出し、年の活性因子がジテルベングリコシドである

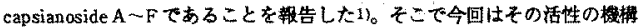
を解析した。

(方法と站果) シシトウ水抽出物を各理カラムクロマトクラフィーにより 分面し、最的的にHPLCKより高括性型の capsianoside F 及び低活性型の

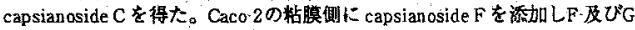

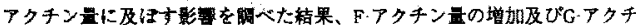

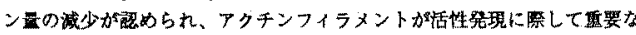

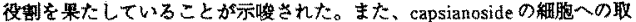
ク达み益を HPLCにより定是したところ、capsianoside FはCの約4㥉取り 込まれており、物質透過性上界活性は細胞への取り迈み量に依存している

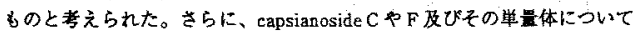

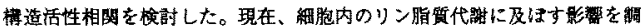

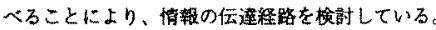

1) K. Hashimoto et al. Biochim. Biophys. Acta (1996), in press.

2Op4 腸管上皮細胞のタイトジャンクション (TJ)における 物翼透過性を上昇させるエノキタケ由来成分 ○奈良井朝子、橋本 憵、荒井䅫一、清水 誠 （東大院農生科・応生化、觧岡悬大・食品栄学科学）

【目的】ヒ卜結腸ガン由来の腸管上皮培養細胞（Caco-2,T84） に毒性成分を作用させると丁Jの状態が迅速に变化し、その変化 が綶胞層の経上皮電気抵抗（TEER）值の低下に反映されるこ とをこれまでに見出した。一方、エノキタケ (Flammulina velutipes）の水抽出物中に、細胞雪性は示さないが、TEER值 苦しく低下させ、上皮細胞層の物質透遇性を上昇させる成分 の存在を認めたので、今回、その活性成分の単離を試みた。

【方法・結果】市販のエノキタケに水を加えてホモジナイズし た後、濾過、遠心分離により不溶物を取り除いて凍結乾燥し水 抽出物の試料とした。透過性膜上に培䅗したCaco-2の管腔側に 試料を添加すると短時間でTEER值は低下したが、細胞の膜賣 傷および代謝活性の低下は長時間の後にも検出されなかった。 加熱処理またはプロナーセ処理した試料てはTEER低下活性が 失われたことから活性成分はタンパク質性の物質であることが 示晙された。現在イオン交換クロマトグラフィー、ゲル清過等 で精製を進めている。

2Op5 タンパク盗のin vivo 消化性と経口免疲原性

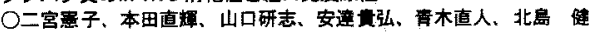

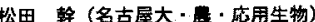

【目的】これまでにマウスに卵白タンバク算を経口投与するとオボムコイト

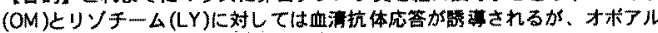

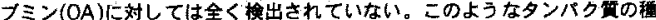

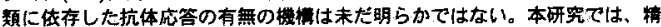

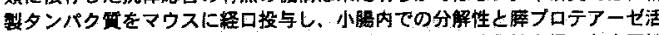

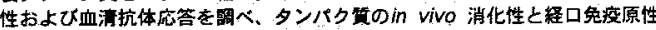
との膊を明らかにすることを目的とた。

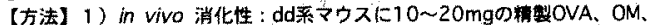

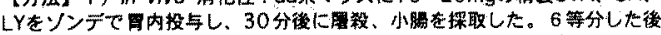
各部位の晹管内容物を回取 LSDS-PAGE、Immunoblot. トリブシン活性测 定用のサンブルとした，2）経口免㾤原性：B10.A系マウスに，一日一回，

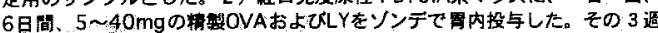

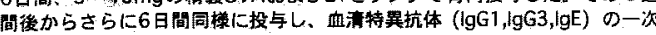
および二次応答をELISALより测定した。

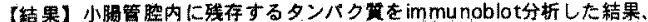

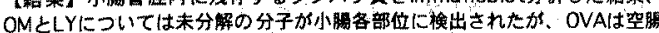

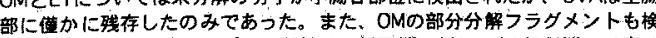
出された。䭪管内のトリブシン活性は、対照群に対してOA投与群では高く

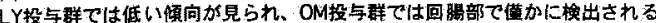

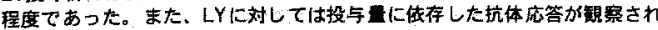
たがOAに対しては無応答であった。幽上の結果から、in vivo 消化性はタン

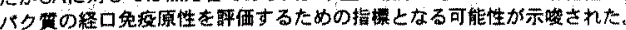

$20 p 6$ オどォイドベプチド gluten exorphin A.5 の小麦グルテンからの

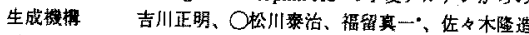

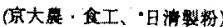

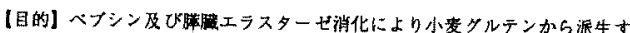
るオヒオイドベプチド gluten exorphia A5 (GYYPT) は経口投与の際にインス リン分級及び学習能促進など興昧深い作用を示すベブチドであるる。っの GYYPT 配列は高分子クルテニン中に15回料り透し存在しているか、てれら のうちどの部位から本ベプチドが派生するのか在梌沚しだ

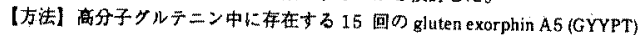

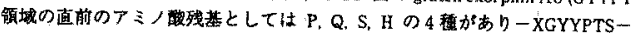
$(\mathrm{X}=\mathrm{P} . Q . S$ または $\mathrm{H})$ で表現できる。この分類に従って GYYPT 列列前倿に

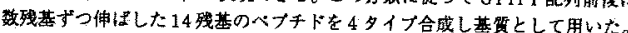
【藉果】4タイの合成ベブチドは、エラスターゼにより異なった切䉼を受 けた。 gluten exorphin A5 はSタイプの合成ベブチドから高收案で得られ、H

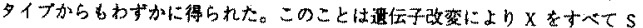
にすることによってその in vivoでの生成を10数倍高めることができること を意味している。なおエラスターぜ唖にサーモリシンやブロチン FNによ。 ても gluten exorphin A5 は生成するが、それらの切断部位についても梌討した。 <文献〉 1) S. Fukudome et al., Life Sciences 57, $729 \cdot 734$ (1995)

20p7 ヒト腸管上皮細胞 Caco-2 の食品蛋白䨢分解ペプチド に詨する応答について

○佐竹 真, 清水 誠 (東大院農生科·応生化)

[目的］消化管内で生成した食品蛋白貿由来のオリゴベブチド は多様な生理譏能を有することが報告されているが小陽上皮層 におけるその透過吸収については末だ不明な部分が多い。そこで 今回、七卜腸管由来株化細胞 Caco-2 t用い、食品蛋白賈由来べ ブチドの腹管上皮層における举勳について観察した。

[万法と結果] 透過性膜（MILLICELL-HA，0.45 $\mu \mathrm{m}$ ) 上下単 居培盖した Caco-2（1 4 日間) の、管腔溉に 豆蛋白而などの醳素分解物を添加し、基底膜側に透過したベプチ ドを逆相 HPLCにより分析しようとした。その結果、添加した ペプチドの透過量はわずかであったが、それ以外に、用いたペブ チド試料に由来するものとは考えられないビークが基底膜側に 出現するのを認めた。特に $\beta$ 一カゼイン分解ベブチドにおいてこ の現象は顕著に観察された。この細胞が放出したと推定される成 分については、現在検討を進めている。

2Op8 中国産冬虫夏草( Condyceps sinensis ) 部萎菌系体工キスの橧理 効果一血粒降下作用、抗ストレス作用

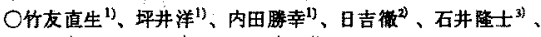

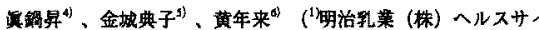

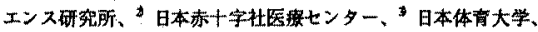

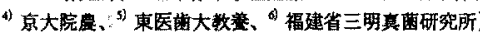

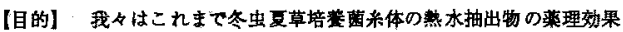

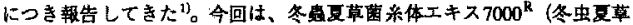

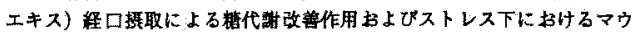

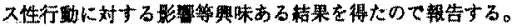

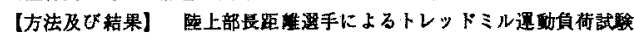

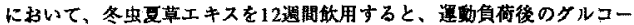

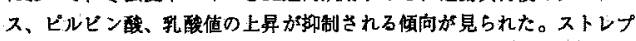

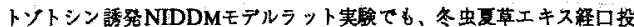

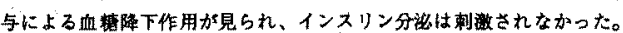

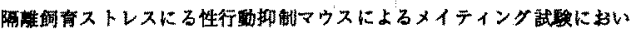
ては、冬虫夏草エキス释口投与による性行的（フラタク形成事）の增加为 見られ、抗ストレス效果が考之ら枕。

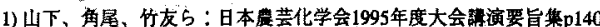




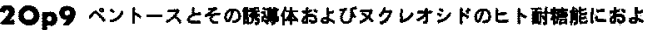
\&す酶

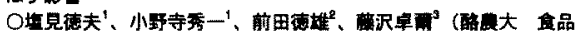

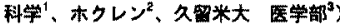

【目的】これまでに、イノン、アデノシン、キシロースおよひフラクトシ ルキシロシドが、ショ第あるいはデンブンと共にラットに糙口投与すると 血蛅上昇を抑制することを軙告*した。今回はこれらのヌクレオシドある

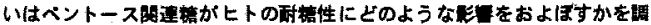
ヘた。

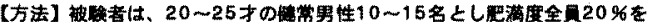

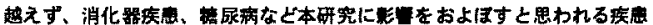

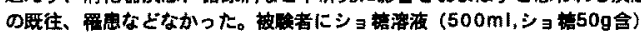

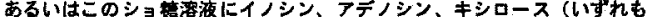
$0.5 ， 1.0,2.5 \mathrm{~g})$ あるいはフラクトシルキシロシド $(12.5,25 \mathrm{~g})$ を加え

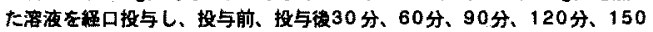

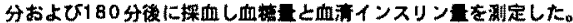

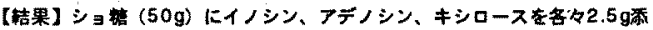

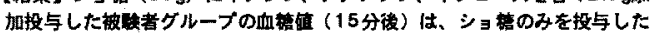
グループよ比へて有害に低く、血青インスリン值あ明らかに低かった。 れらの和加量を0.5gに減少させても上述と同接の㑔向がきめられた。フラ

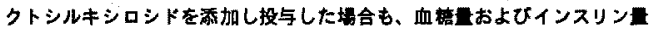
の上界は㧕制された。

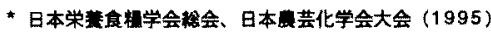

2Op10バナバ葉の熱水抽出物の $\alpha$ ーアミラーゼ活性阻害 作用 O竹内久直、林，武司、角田隆巳*（静大 農・応生化、**伊藤園中央研)

(目的)フィリヒンでバナバと呼ばれているオオバナサル スベリ（Largerstroemia speciosa L.）葉の繁水抽出物

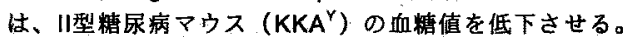
特に、熱水抽出物を合成吸着樹脂HP-20によるカラムク ロマトグラフィーを行い、HP-20吸着分画がその有効成 分であることか明らかにされているが、その作用機模につ いては分かっていない。本研究では、その機作として考え られるぶた腈䑏 作用について検討した。

(方法・結果) 酸としてシグマ製フタ膵䑏 $\alpha$-アミラー

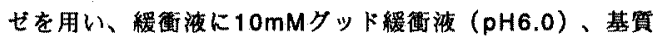
にカルボキシメチルアミロースを使って、同䣼素の活性を 娜定した。この湘定方法でバナバの同醉素活性に対する阻 害奻果を調べ、その阻害が捛抗か非拮抗かについて検討し た。その結果、バナバの同醇素活性に対する阻害奻果は、 非拮抗であることが推定された。

2Op 11 生菜成分の $\alpha$-グルコシダーゼ阻害物質 (2) - baicaleinの峬䟕突スクラーゼに対する阻害効果一

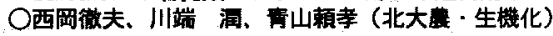

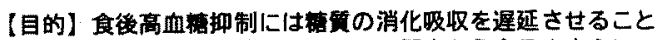
か有効と考えられる。演者らは、この锶点から食品を中心に $\alpha-$ クルコシターぜ阻害物䖵の探索を行い、黄荅のメタノール抽 出物の酢酸エチル可溶中・フェイール性画分から阻害物浜とし

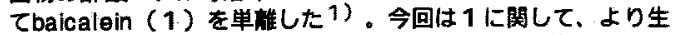
体に近いアッセイ系で阻害効果を梌討することを目的とした。 [方法およひ結果) 1 とその類模体のラット小腸スクラーゼに 対する抟造活性相関について検䛌を行った結果、トリヒドロキ シベンソイルル基が関与していることが示㖫された。さらに、1 はヒト結腢䠛由来株化細胞Caco-2のホモジネート酥素に対し ても阻害奻果が認められた $\left(1 \mathrm{C}_{50}=2.2 \times 10^{-4} \mathrm{M}\right)$ 。現在、小臊 上皮細胞のモテル系として透過性膜上に培養したCaco-2を用<smiles>O=c1cc(-c2ccccc2)oc2cc(O)c(O)c(O)c12</smiles>
いて。化合物の阻害活性に関 して検徱を行っている。

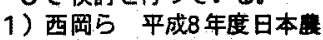
芸化学会北海道支部春季学術 請演会要旨集 P.25

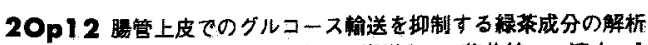
○鈴木美㯖、薩 秀夫、河岸洋和 1、荒井綜一、清水誠

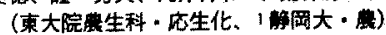

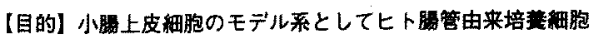
Caco-2を用い，小晹におけるグルコース取り込みを眮知する物管 を食品中より探象したところ、緝荣抽出湤中にグルコース㻌送を

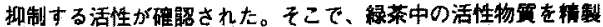
し、その構造を明らかにすることを試みた。

【方法と結果】まず、悢苏熱水抽出物をSep-pak (ODS)にかける

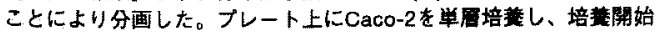
10日前後に緑茶画分を添加して15分間ブレインキュベートした。 細胞を洗浄した後、朝ラベルしたグルコースを加えて10分间 インキュベートした。紐胞を可溶化し、細胞内に取り込まれだH を測定することによりグルコース輸送量を第出した。その結果、 30\%アセトニトリルでSep-pakから涴出される面分が最も强くグル コース取り込みを抑制した。HPLC分析の結果，本画分には裸数の

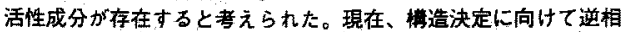
HPLCによりこれら活性成分の情製を進めているところである。

20p13 七卜晹管絧胞Caco-2におけるタウリン梌送系の制御 ○嵟 秀夫、渡辺宽人、荒井綜一、清水 晹 (東大院费生科=店生化)

[目的]滨者らは前回の本大会で、ヒ卜腸管細胞Caco-2におけ るタウリンの唋送がシステムßと呼ばれるアミノ酸徐送系を介して おり、また培养条件の変化によりその輸送活性が制御されること adaptive regulation）、報告した。，今回、タウリン榆送系の制制に ついてさらに検钨をすすめたので報告する。

[万法] プレート上にCaco-2を単層培養し、培美開始後14日目 ヒトリチウムラベルしたタウリンを加えて37゚C゙でキュベーー

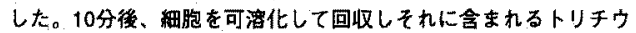
么量を測定することでタウリンの輸送活性を湘定した。

[結果] タウリンを過剩に含んだ培地で培善した後タウリン翰送活 性を的ぺたところ、渝送活性は過剩条件下での培墓時間及びタウリ

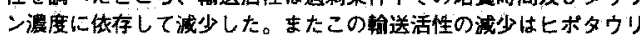

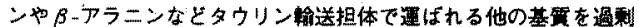
にした場合でも同样にみられた。一方、 $\alpha$ アミノ䤒を過制にした堨 合では变化がみられず、この輖送活性の娍少はタウリン耣送担体の 基曾によって引を起こされることが明らかとなった。ノーザン解析 により锶べたタウリン輸遂担体のmRNA量はタウリン過制条件下て 娍少しており、これよりこのダウンレギェレーションは少なくとも 転写レベルでの制御を介していることが示暖された。

2Op14 ヒ卜腸管細胞Caco-2におけるタウリン榆送に影霓する 食品由来成分の梒䨛 清水 解、O金山敦宏、薩 秀夫 （東大院農生科－応生化）

[目的]食品中に存在するタウリンは小得上皮細胞に存在するタ ウリン梌送担体によって吸収されるが、一方で食品中にはタウリン の輸送に影䭗を与える因子が存在する可能性もある。しかしなが ら、そのようを機能をもった食品由来因子は現在まで知られていな い。そこで、ヒ卜小腸上皮細胞のモデル系としてヒト結腸癌由来株

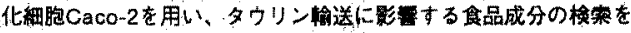
行った。

[方法］各種の食品を水及びエタノールで抽出し、遗心迈理後の 上清を凍結乾燥したものを試料とした。ブレート上に単層培器した Caco-2に試料を添加して30分间プレインキュベートし、洗浄後卜 リチウムラベルしたタウリンを加えた。10分後細胞を可濐化し、取

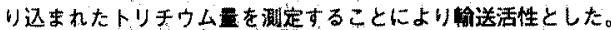

[結果] 20種䫏以上の試料について䀦べた結果、ゴマの50\%エタ ノ一ル抽出物にタウリン輸送活性を約 $70 \%$ 阻害する活性が見出され た。この本抽出物は他のアミノ醞特送活性には有意な影霖を与えな がったことから、タウリンの同送を特異的に阻害することが示喽さ れた。現在さらた本抽出物中の活性因子の精製をすすめている。 
2Op 15 トゥガラシの acetyl-CoA carboxylase 阻家物而

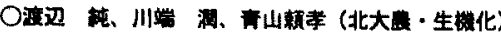

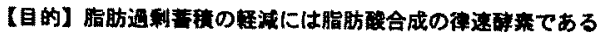
acetyl-CoA carboxylase の阻害か有妨と考えられる。遗者らは、この

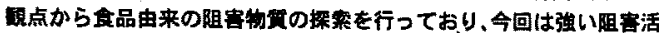

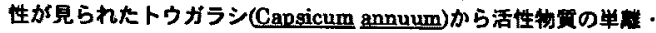
同定を行った。【方法およひ苦果】ラット肝 acetyl-CoA carboxylase による malonyl-CoA およひ ADP 生成の抑制を指拯に、トウカララ のメタノール抽出物を雾綝分面、シリカゲルカラム、ODS カラム、

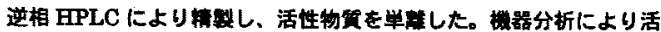

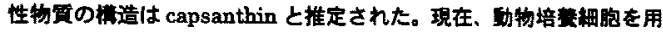

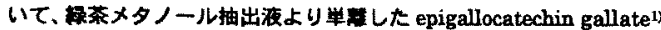

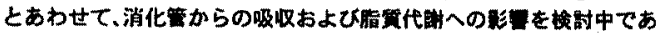
る.

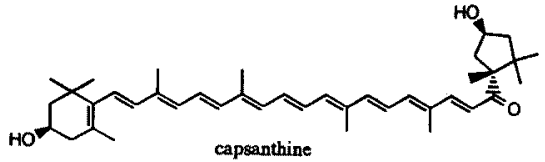

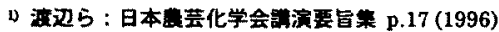

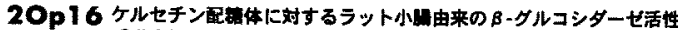

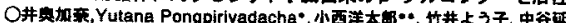

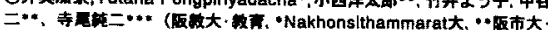

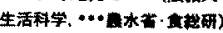

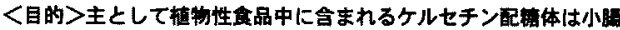
内のßーダルコシターゼにより加水分解を受けると考えられるが、配

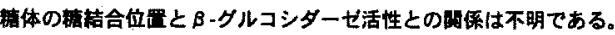
そこで、Quercetin-4'-glucoside (Q4'G), Quercetin-7-glucoside (Q7G), Quercetin-3-glucoside(O3G)，及び rutinを用いて醋活性 を比较梌时した。

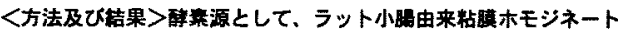
と市眅標品 (Caldcellum Saccharolyticum由来)の 2 植数を用いた

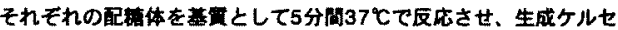

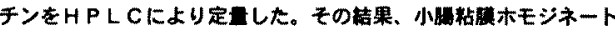
と市販福品のいずれにおいても04Gの加水分解活性はQ3G、O7Gよ リ高かった。また、rutinは反呪しなかった。

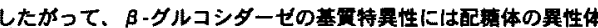
による相造加あり、Q4'Gは小男内て03GPO7Gより登易に加水分 解されてケルセチンになると推渭された。

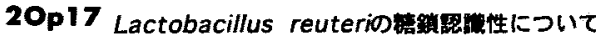

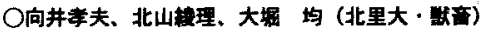

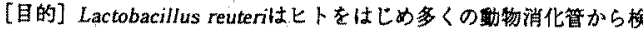
出される乳酸菌であり、その利用性を考える上からし晹内定着因子 䓂明らかにすることは重要である。我んはL，reuterの晹内定着性に

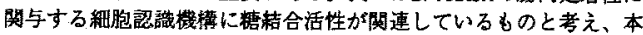
研究では複数の菌株を用いて糖鎖認撞能を調べた。

[方法]供試菌株はJCMから睛入した6落株を用いた。これらの糖結

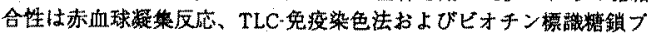
ローブ法による複数の方法で揄討した。

[結果]5種類の動物由来赤血球を用い、米上にて末琏理赤血球およ ひノイラミニダーぜ処理血球に対する凝桌活性を調へた結果、供試

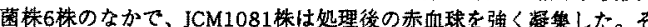
こで多数の糖類用いて阻害試験行うと、Galで弱く、O型糖制克 会もアシアロ糖タンバク筫で强く阻害された。またTLC筧疫染色を行

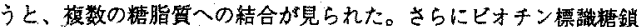
ブローブを用いた結合試駼から非還元末端Gal残基を含む糖鑍に結合

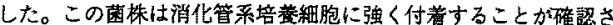
れ、現在、糖鎖認識能と細胞への付着性との関連性を群析してい
$20 p 18$ 莭カルシウムの生体利用性 ○西澤 直行, 大久保圭祐，長澤孝志 (岩手大·鹿・応用生物)

[目的] 食品カルシウムの利用性を高めようとする研姦が行 われささまざまなカルシウム食品が開発されている。演者ら は,カルシウムを豊富に含を酿卵のカルシウムの吸収性につ いて主に研究してきたが, 今回, 更に改良を加えて、そのカル シウムの利用性を検討した。

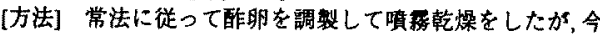
回、卵黄を含まない酷卵を調製して実験に用いた。4週龄雄 ラットに, 酿莭由来カルシウムを含む飼料群(S群), 炭酸カル シウム群(C群),及び醅カルシウム群(A群)の3群に分けそ れそれのカルシウム含量として0.3\%の飼料を21日間与之，カ ルシウムの出稆実験を行った。

[結果] 材料のカルシウム含量は $14.4 \mathrm{~g} / 100 \mathrm{~g}$ であ，従来のも のに比べほほ50\%高かった。又、コレステロールは汪とんど含 まれていなかった。C群及びA群の見掛けのカルシウムの吸 収事は80.4\%及び82\%に対して、S群の吸収率は95.6\%と有意 に高い值を示した。これらの結果は、䣫卵のカルシウムがカ ルシウム菜材として有效である事を示惨した。

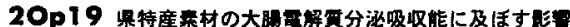

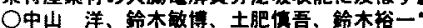

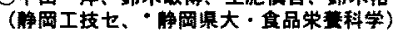

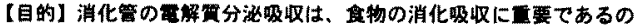

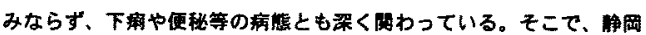

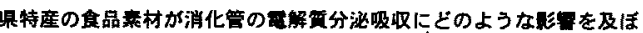

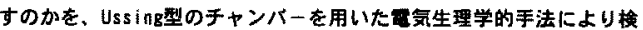
时したので啹告する。

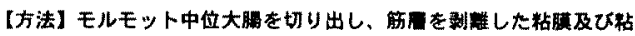

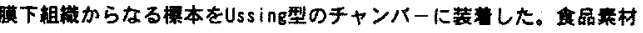

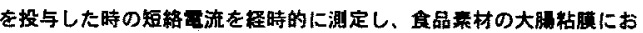

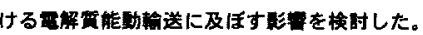

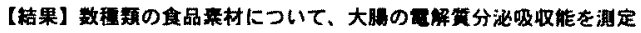
したところ、ワサビ茎抽出物にC゙分泌を抑制する奻果か見られた。 また、ワサビ檠抽出物は、氞気的フィールド刺流及び5-HT投与による

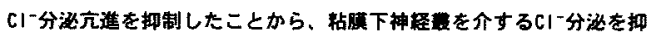
制していると质えられた。これらの結果よりワサビ基が抗下解奻果を 有する貴品秦材として期待でる。

20p20

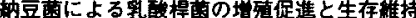

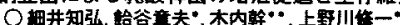

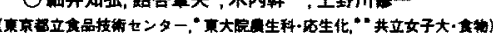

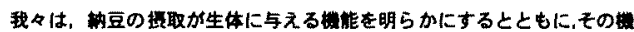

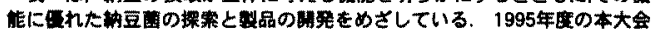

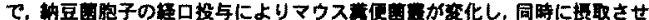

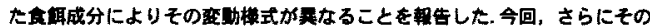

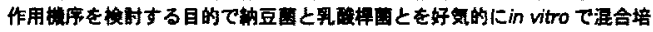

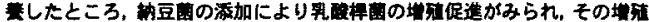

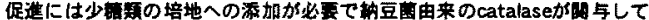

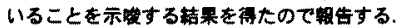

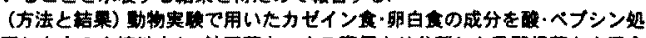

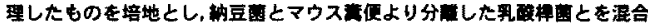

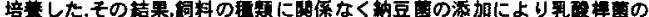

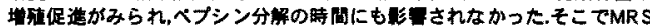

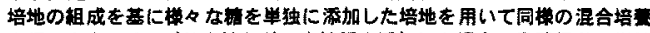

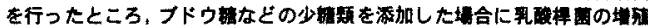

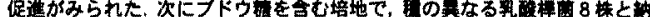

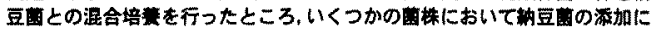

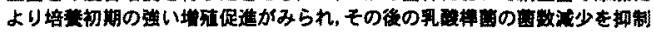

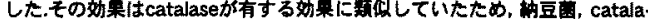

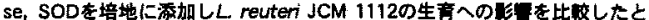

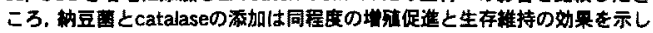

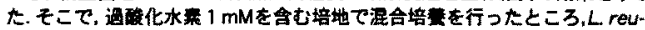

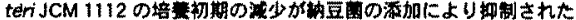




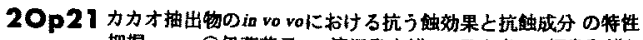

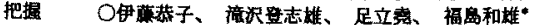

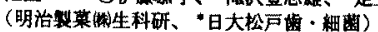

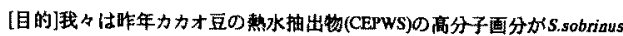

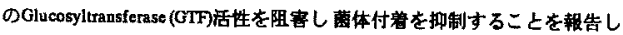

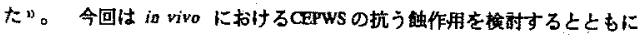
CEPWS中の有効成分の精製と性状解析を試みた結果について報告する。

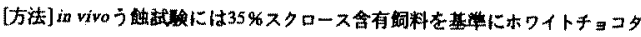

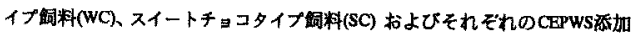

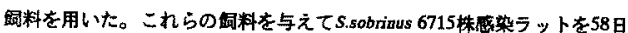
間鉰育後、下频のう触スコアーをKeyes法で湖定した。CEPWS中の有効成

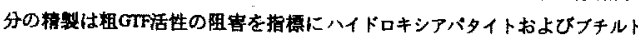
ヨパールのカラムクロマト处理により分画し踥した。

結果〕う蝐スコアーはチョコタイプ絢料群は基本餇料群より、またCEPWS添加 WC群はWC群よりす有意に低かった。この結果からCEPWSの抗う蝕作用か in vivoにおいても示实された。CEPWSの高分子画分をカラムクロマト姏理 することにより比活性が約倍上昇した画分が得られた。この画分を分析し

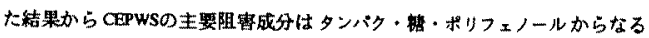
高分子物刑であると考えられた。

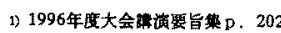

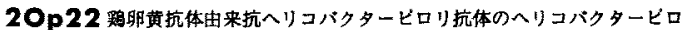
リに及に名影吾

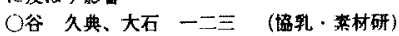

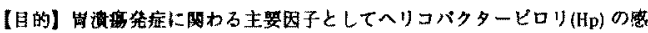

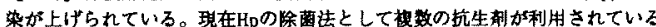

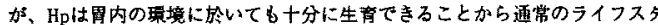

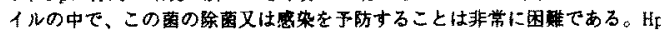

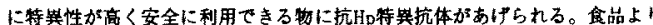

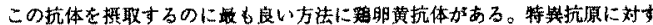

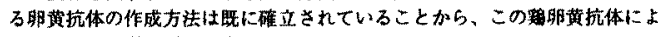
るHp制图作用等の梌尌を行った。

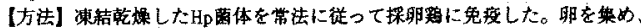
中井らの方法に従って明黄より抗体を精榷した。In vitroにて、抗Hp抗体の

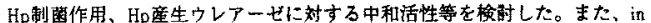

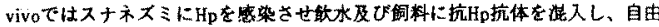

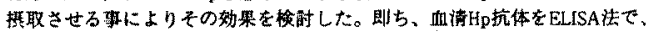
メウレアーゼに対する応管性をBLAcoreにて测定した。

【結果】抗Hp抗体のHp增殖抑制作用は非常に高く、その他の落に対しては 作用をボさなかった。Hp由来ウレアーゼに対しても高い反応性を示しその括 性低漸度で中租したが、しかしナタマメ由来ウレアーゼにはほとんと作用 しなかった。In vivol゙おいて抗Hp抗体を投与することによりHp慗架が有意に

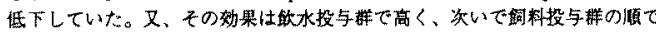
あった。以上の結枼加らHp制商作出に本㧧体が有协であることが示された。

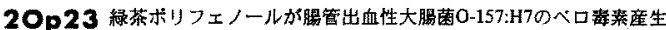

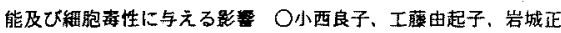

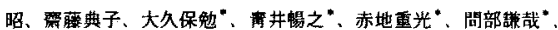

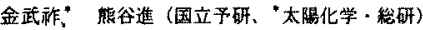

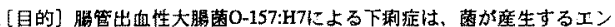
テロトキシンであるべロ毒の作用で発症する。しかし今た、有效な予 防法俚砤立されていない。そこで我々は緑茶から抽出したボリフェノー

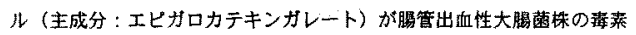

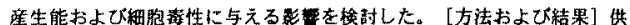

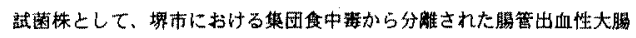

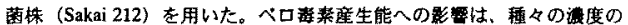
緑茶ボリフェノールを含む感受性ブイヨン培地にて培虽し短時的に上清 中のべロ弯 (VTI およひVT2) をRPLA法で検出することにより求めた。

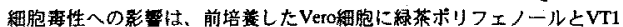

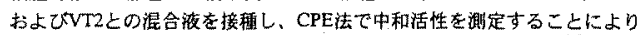

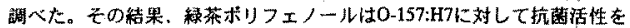

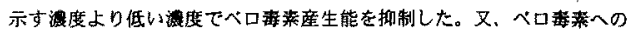

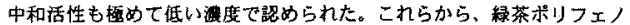

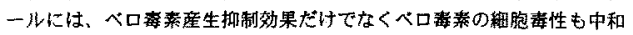

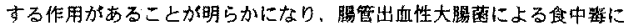
对して予防効果をもつ最品成分である可能性が示唆された。
$20 p 24$

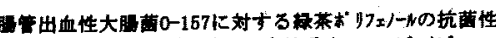

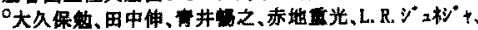

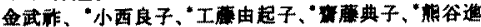
(太化学・研、“国立予研)

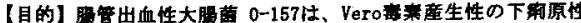

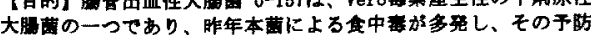

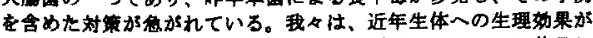

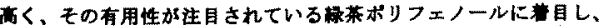

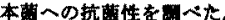

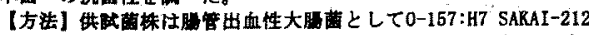

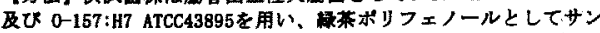

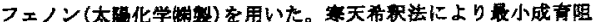

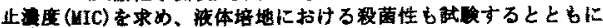

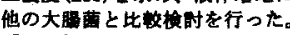

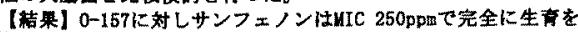

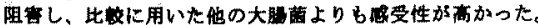

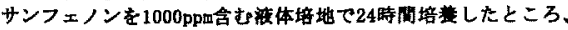

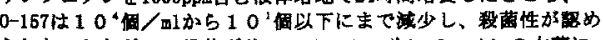
られた。したがって禄茶杖りフェノール、サンフェノンの本菌に 対する有婉性が示された。

$20 p 25$ 羅布麻茶の病原性大腸菌0-157に対与る作用 ○荒俣陽子、古田要介、堀りつ子、米沢実、松原信之 南新三郎 (䈏山化学工策(㧣)綜合研桇所)

〈目的〉羅布麻茶は中国において古来より広く飲用され、血圧 低下作用をはじめとする各種作用が知られている。今回、食中 嗑の原因となっている病原性大腸菌O-157に対する羅布麻茶の 抗菌作用扰よぴO-157の素活性に対する影響を検狽したので 報告する。

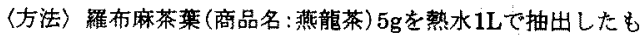
のを $0.5 \%$ 羅布麻茶とした。Mueller-Hinton brothで調慗した

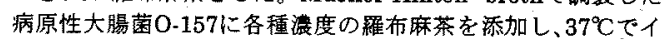
ンキュベートし、1、3および5時間後の生菌数を測定した。ま

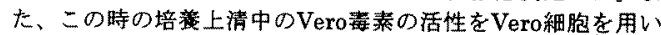
て測定した。

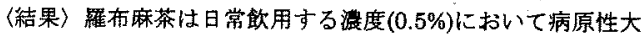
腸菌O-157の生育を抑制し、培盖上清中のVero毒素の殺細胞活 性を顕著に低下させた。この毒素活性抑制作用の詳細について 併せて報告する。

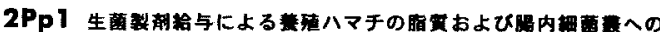

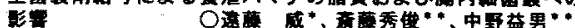

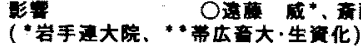

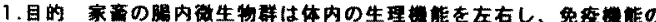

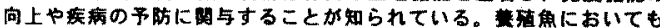
同模の作用が期持される。しかし、魚の睡内物物の作用については

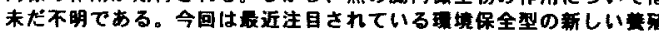

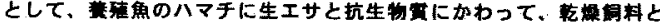

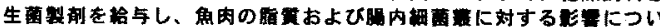
て鯛へた。

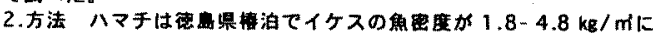

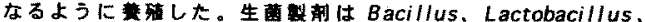
Str ep tococcus. Cl ostridium. Sacchar omyces およひ Candict

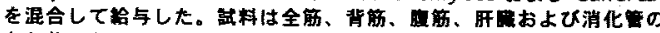
各部位に分けて探取した。后䆛はクロロホルムーメタノール系を用い たBligh-Deyer 法で抽出し、成腰肪覆はガスクロマトタラフィー

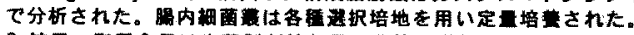

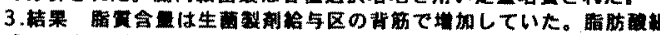

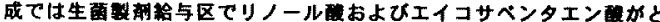

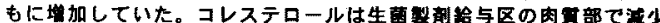

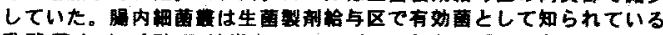

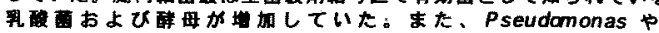

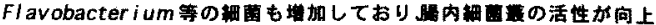
していることが示睹された。

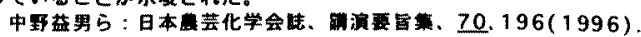


2Pp2

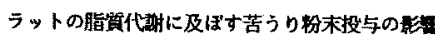

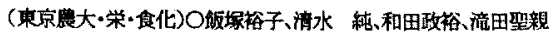

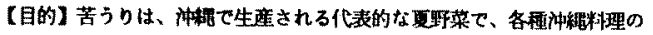
泰树として用いられている。この野菜は、特有の苦みを有することやビタ ミンC含量の高いにとが特徽であるが、その掝能性についての報告は少小

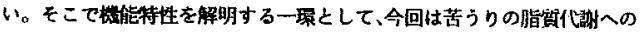

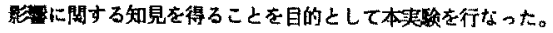

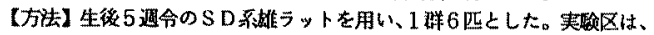
コレステロール無添加食（I区）と沶加（II区）の2区とし、雨区に対

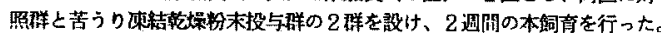

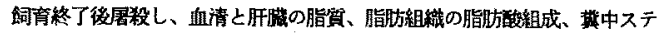
ロイドを剆定した。

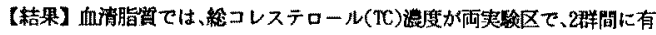

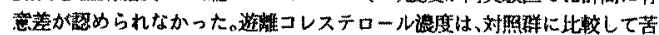

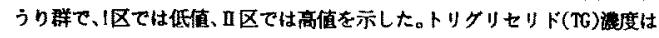

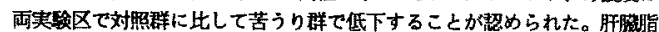
賀ては、T算度か曱実駼区て対照群に比して苦うり群て低值を示した。脂

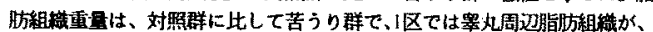

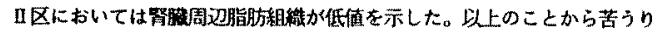
の脂筫代期への脂影水示喽された。

2Pp3 ドコサへキサエン酸レベルの異なる油脂投与による ラットの库吸機能への影缶

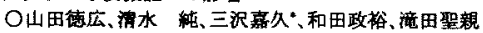

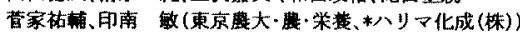

【日的】 $\mathrm{n}-3$ 系多価不和和脂肪酸(PUFA)は多㥞な生理譏能を有し注目 を集めているが、一方でnー-3PUPAを多く含を魚油を多量に婹取した場

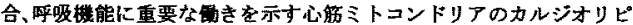
ン(CL)のリノール酸(LA) の割合が低下し、再吸機能が低下することが 指㜔されている。そこで、魚油中に多く含まれるドコサへキサエン酸 (DHA)を取り上げ、そのレベルを買にして与えた堨合の酸素消椠速度 タトクロームーc-オキシターゼ(cyto-c-oxidase)活性及び心矔CL脂肪酸 組成などに及ほす影喽を梌討した。

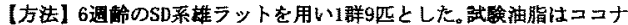
ッッ油にLA(922)およじDHA(92X)を湜合し、P/S比を1とし、DHAのレベルを

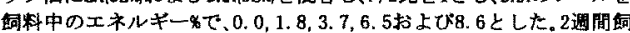
育後酸素消费速度、cyto-c-oxidase活性及び心愺 CL脂肪酸組成などを 泚定した。

【結果】铝料のDHAレハルの上昇とともに心满CLのLAの割合は城少し た。酸素消费速度(State3) とcyto-c-oxi dase活性はDHAレベル1.8で有意 に低下し、それ以上DHAレベルを高名有意な変化が諗められなか った。これらの結果より、DHAレハル1.8以上では酸等消费速度の著し い低下路起こらないのではないかと示唆された。

2Pp4 ドコサへキサエン酸（DHA）の楞取による組絹脂筫過酸化

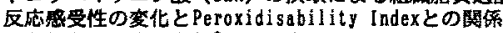

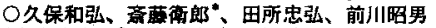
（果京晨大、“国立践康・采養研）

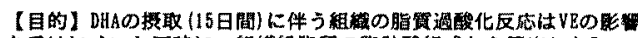

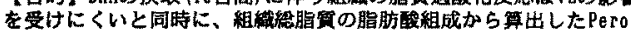
xidisability Index (P-Index) 加5予娜される程には艺進しないと

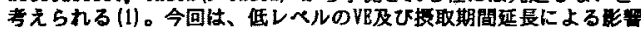

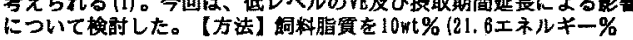
(en\%)、DHAレヘルルは8.7en\% (コントロールはリノール酸9.0en\%) とし、 ฟBレヘルを1，8，20及ひ6010/100g diet(コントロールは8[U)と

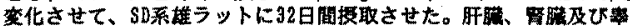

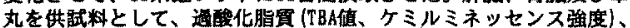

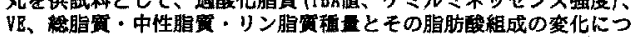

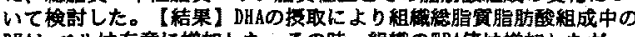
DEAレベルは有意に增加した。その時、組械のTBA值は增加したか、

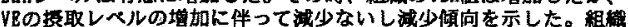

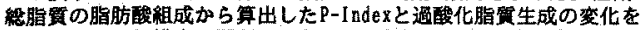

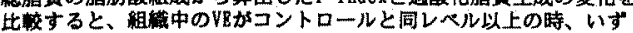

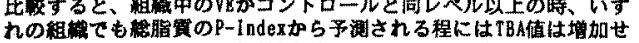
す、(1)の結果について再㯰性を礁琵した。以上の結果より、DHA授

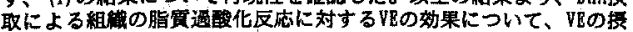
取量のみならすての报取期間がをく閶与すると考えられた。また、

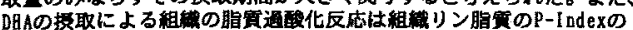

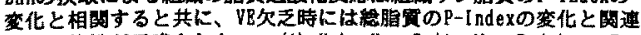
卞可能性が示唆された。 (1) Kubo, K., Saito, M. Tadokoro, T. and Maekara, A., Br. J. Nutr. (subritted)

2Pp5

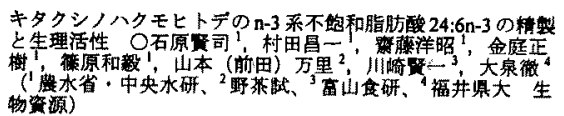

【目的】若独湾で探取されたキタクシノハクモヒトデ (Ophiura sarsi Latken)の脂算中には比的高い割合(螕脂肪酸中 $16.1 \%$ ) 6,9,12,15,18,21-fetracosahexaenoic acid (24:6n-3)加含まれている。24:6n-3 の代期や生理活性についてはこれまで報告がない。本研究では24:6n一

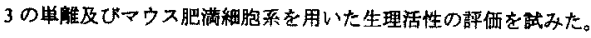

【方法と結果】キタクシノハクモヒトテの総脂策を抽出、メチルエス テル化し、硝酸銀薄層クロマトグラフィー、递相韵速液体クロマトク ラフィーを用いて 24:6n-3を純度 95\%以上(GC)に䋖制した。炊に、

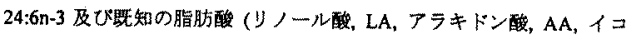
サベンタエン酸、EPA、ドニサヘキサエン酸，DHA)老用い、マウス肥満 細胞株 MC/9のヒスタミン含量に対する影響を調へた。その結果、 $\mathrm{AA}$ はヒスタミン含贯を增加させたが、n-3 采高度不绚和脂肪酸である 24:6n-3及びEPA、DHA は有意に诚少させた。LAにおいては装野は見 られなかった。

2Pp6

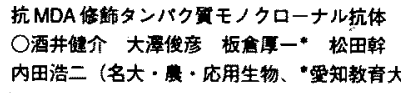

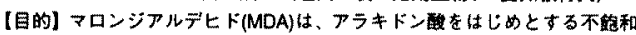

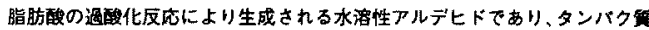
リジン牫基なとの一級アミンと反応し様々な付加体を生成する。前年度の本 大会にて MDA と No-acety-Lysの付加体の一つである、NE-(2-propenal) type

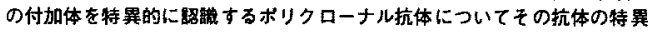

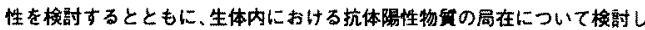

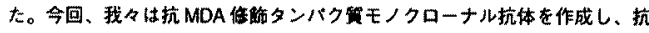
体の特異性を中心掼討した。

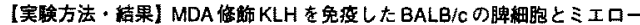
マ (P3XAg8.653) との姆盷眙合により288 wellのハイブリドーマを得た。

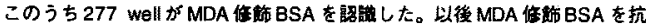

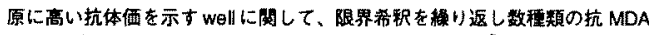
修飾タンバク留モノクローナル抗体を得た。これら抗体の特異性の決定には、

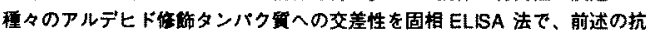
体同槏 MDA と N $\alpha$-acetyl-Lys に由来する三種の付加体については競争的 ELISA 法により梌尌した。むた、銅䣬化LDL中における MDA-Lys 付加体の 生成をELISA法、Western blotting 法により㮆跱し、酸化ストレス病然にお けるパイオマーカーとしての抗体の役割について検到した。

2Pp7 発癌性アルデヒドによる蛋白算修飾に関する免疫化学的研究 内田浩二、O兼松正道、酒井揵介、大澤俊彦、眷國伸哉” （名大・豊・店用生物”京大·医）

【目的】アクロレイン (ACR) は、食用油の加熱やガソリン、ブラ

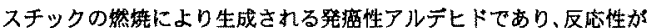
非常に高くアミンやチオールなどの求核基と反応し付加体を形成す る。本研究では、抗ACR 修飾蛋白筫抗体を作成し、その特異性及び エピトープ解析を行うとともに，制誘発によるラット発癌系における ACR 付加体の免疫化学的娭吋を行った。

[万法]抗 ACR 修飾蛋白䝷抗体は、10mM ACR と $2 \mathrm{mg} / \mathrm{ml} \mathrm{KLH}$ を $37^{\circ} \mathrm{C}$ て 24 時間反応したものを抗原として用い、ウサギに免璂するこ とで得た。

【結果】ACR 修飾蛋白筫のアミノ酸分析を行ったところ、Lys に特 異的な減少が見られた。抗 ACR 修飾蛋白質抗体は ACR に特異的で あり、他のアルテヒド修飾勇白筫に対する反度性は全く睍られなかっ た。一方、ラットに対する铁ニトリ口三酢酸（Fe-NTA）投与におけ る急性略障害について免疫染色を行ったところ、近位尿細管鹪害部位 において強陽性であり、证 vivo における酸化ストレスモデルにおい て ACR 修飾蛋白質の生成が証明された。 
2Pp8 リノール酸ヒトロロペルオキシドと生体アミンの付加体を䁌する 扰体の特筫性とその庥用

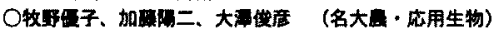

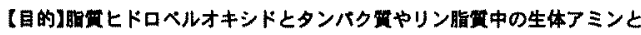
が反忘し、老化色基であるリポフスチンを生成することが報告されている。 そこでリノール酸ヒドロベルオキシドの1つである 13-Hydroperoxy$9(Z)-11(E)$-octadecadienoic acid (13-HPODE) \& Keyhole limpet hemocyanin (KLH)との反庥物を抗原としてりサギに免度することにより、

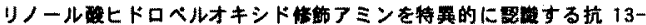

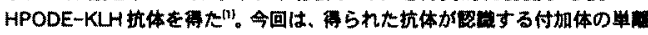

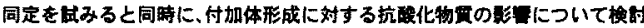
したので併せて報告する。

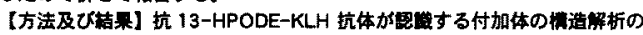
ため, 13-HPODEと Bz-Gly-Lys

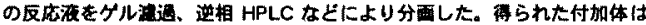
NMRにより 13-HPODE由来の化场とりジンの ると示战された。現在はこの付加体の清落についてMS、NMRなどの機器分

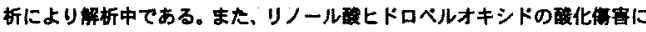

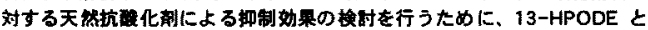

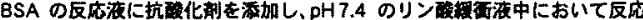
を行い，付加体形成拥制奻果について纣 13-HPODE-KLH 统体を用いた ELISA法により平価を行った。

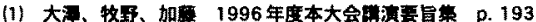

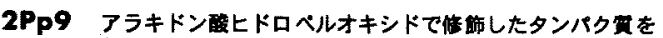

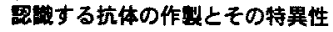

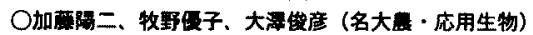

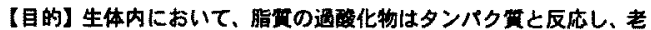
化色素であるリボフスチンを生成することが推測されている。演者ら は昨年度の本大会でリノール酸ヒドロベルオキシド侮飾タンバク置 に対する抗体の作裂について報告しだ。今回はアラキドン酸に由来

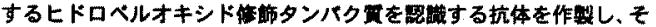
の特翼性を畔べたので報告する。

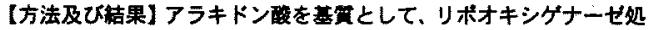
理により 15-HPETE (15-hydroperoxyeicosatetraenoic acid) を铜整 し、タンパつ算と $37^{\circ}$ Cで反応を行った。アミノ酸分析を行ったとこ ろ、リジンやヒスチジン残基の清少が思められだ。15-HPETEとKLH (keyhole limpet hemocyanin)の反底物をウサギに免寉し、15-HPETE

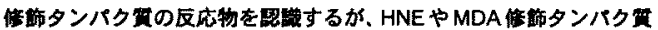
とは交差しない抗 15-HPETE-KLH抗体が得られた。この抗体を用い、 部イオンやラジカル発生用であるAAPH で酸化したしDLにおいて抗

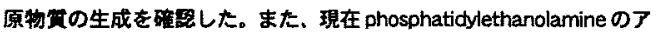

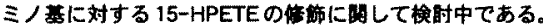

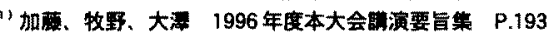

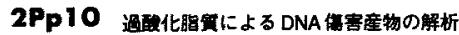

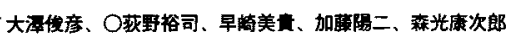

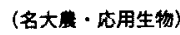

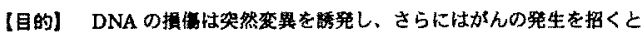
孝えられており、生体にとって重大な意味を持っている。䭫伤の要因として

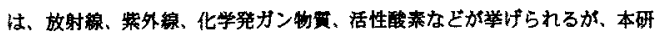

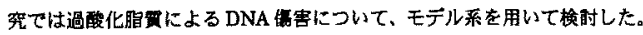

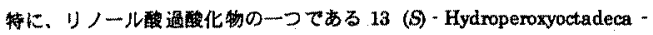

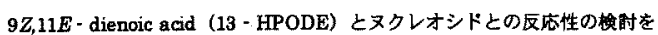

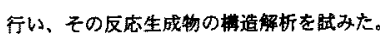

【方法及び桔果】 DNAを構成する4つの各ヌクレオシド（dA，dG、dC、

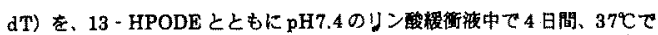

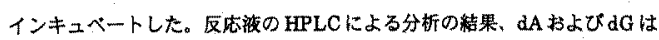
13 - HPODE と高い反応性を示し、さらにそれそれの反応において、13 HPODE との反志生成物に由来すると思われるピークが蚞出された。現在，

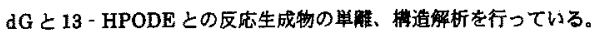

2Pp11 カンタキサンチンによろベルオキシラジカル捕捉反応

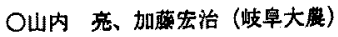

[目的]カンタキサンチン（Can）をはしめとするキサントフィル

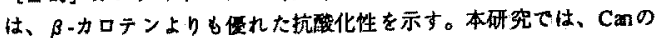
フリーラシカル捕捉反应㙨楎を解明することを目的に、Canの反応 生成物の槽造と脂貿過酸化抑制時のCanの挙動を明らかにした。

[万法] Canをベンゼン中37Cてラジカル反応開始教(AMVN)と反庆

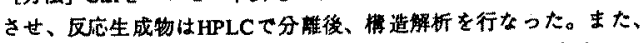
リノール酸メチル過酸反応揤制時のCanの反店生成物を剣討した。

[結果] CanをAMVN由来のベルオキシラシタルと反応させると、 主要反応生成物としてCanのアルアヒド体（1）とエ录キシ体（2

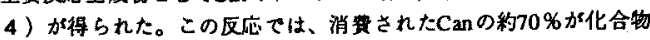
1-4kなっており、これらの化合物生成加Caによるヘルオキシラ シカル捕提の主要反応と考齐られた。また、Canはリノール酸メチ ルヒドペルオキシドの生成を抑制し、Canの诚少にともない化合 物 1-4が生成した。以上の結果より、Canの抗酸化性はベルオキシ ラジカルと反庥して生した化合物が反応系て比䡈的安定てあること によるものと推定した。

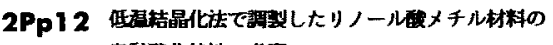
自䣦酸化特姓の考察

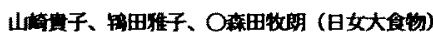

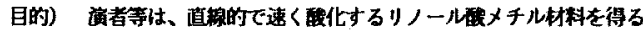

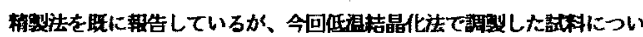

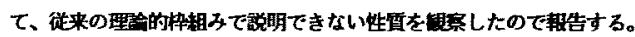

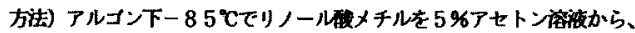

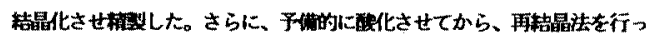

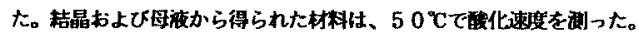

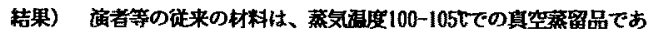

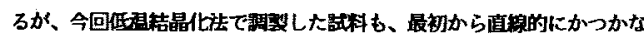

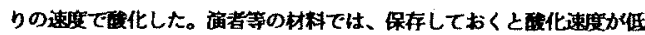

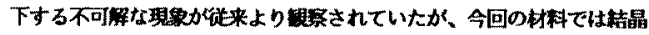

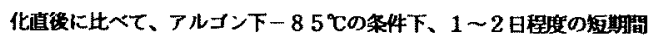

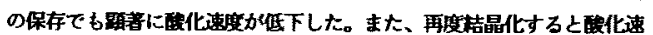

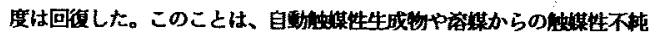

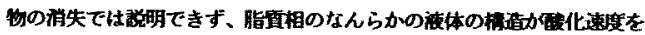

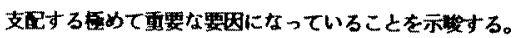

2Pp13 ホスファチジルコリン過酸化物の熱分解に対する抗酸 化剂の扸制奻果

馬場直道, 高橋行江, OMd. Khorshed Alam, 中岛修平，金子幸夫*（岡大・農。*都老人研）

【目的】リン脂留過醊化物は生体に対して殆ど需性を示さない ことを。最近，我々は明らかにした。しかし，その熱分解で生 成する低分子化合物は毒性を示し，食品の重大な劣化を招く。 本研究では、ホスファチジルコリン過硪化物 (PC-OOH)の熱 分解に対する抗酸化郕の抑制好果を調べた。

【方法・結果】リノール酸、ステアリン酸を出発原料とし、大 豆リボキシゲナーゼ及びPseudomonas 由来リパーセ触媒反応 とヒドロペルオキシ基の保墔・脱保讙およU゙DCC/DMAP法に よるリゾホスファチジルコリンのアシル化反応の組み合わせに より、PC-OOHを合成し、このものをメタノール溶洨 $(25 \mathrm{mg} / 0.5 \mathrm{ml})$ とし，抗酸化剤の存在下， $60^{\circ} \mathrm{C} に て 24-96$ 時 間加熱した。分解せず残存するPC-OOHをHPLCIODS， $\mathrm{CHCl}_{3} / \mathrm{CH}_{3} \mathrm{OH} / \mathrm{H}_{2} \mathrm{O}$ によって経時的に定量した。その結果, セサモール、BHT等が有意義な抑制効果を示すことが明かに なった。 
2Pp 14

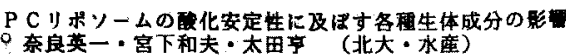

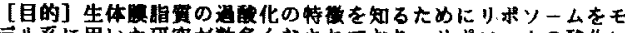
テル系に青いた研究加数多くなされており、リポソームの祚化に

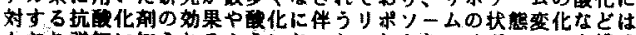

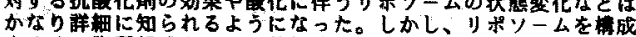

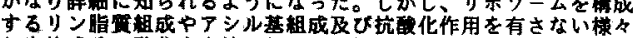

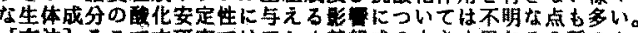

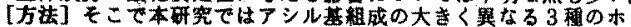

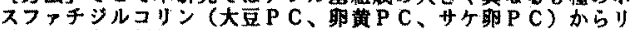

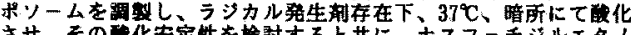

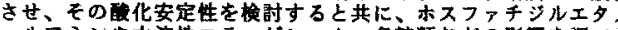

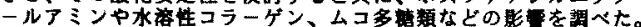

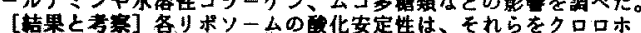

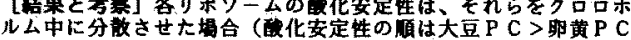

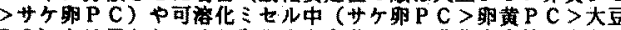

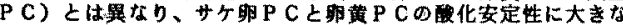

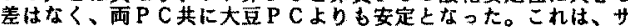

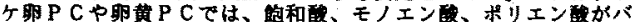

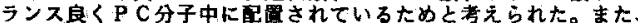

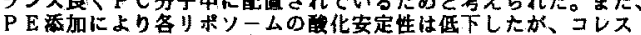

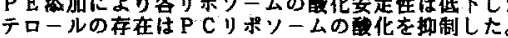

\section{Pp15 タンバク更を用いて水溶洨中に分散させた} 高度不醔 TGの酸化安定性

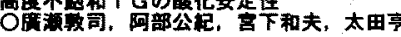

（北大·水童）

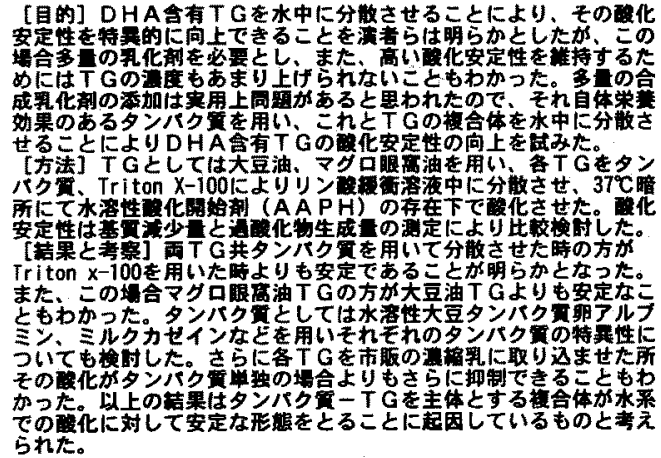

2Pp 16

水系におけるリノール酸ヒドロペルオキシドの 安定性に対する食品成分の影霫

O西池珠子、市川継、菊川紀子、高村仁知、 的場程佳（奈良女子大・食物）

【目的】食品中における脂肪酸ヒドロベルオキシドの安定性 については種々の論境があるが、その詳細については明らか でない。演者らは、食品中におけるその安定性を知るために、 水系におけるリノール酸ヒドロペルオキシドの安定性に対す る種々の食品成分の影慗を調へた。

【方法と結果】種々の絽、アミノ酸、アスコルビン酸などの 水溶液にリノール酸ヒドロペルオキシドを分散させ、一定温 度に保った。経時的に溶液中のリノール酸ヒドロペルオキシ ドを妯出し、残存率を調ぺた。リノール酸ヒドロペルオキシ ドの分析には順相HPLCを用い、共役ジエン模造を有する 9,11 オクタデカジエン酸を内部提準として、234nmで険出を 行った。その結果、糖類はヒドロペルオキシドの分解に影算 しないこと、ほとんどのアミノ酸類は分解を排制すること、 アスコルビン酸は分解を促進することが明らかになった。

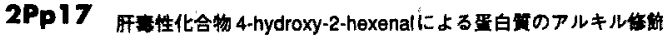

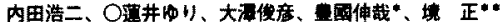

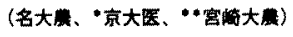

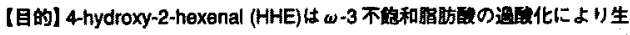

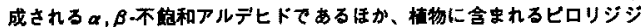

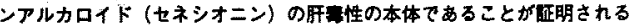

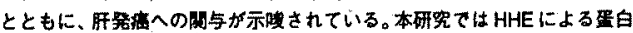

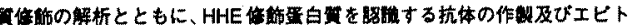
一フの解析を行った。

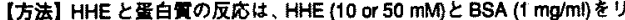

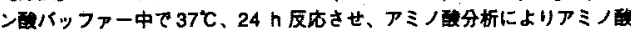

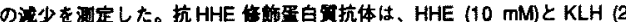

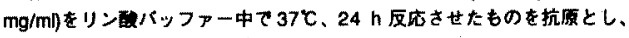
NZWラビットに兔症し、作糔した。

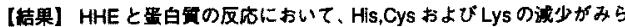
れた。得られた血湆を用いてELISAを行ったところ、他のアルデヒド女数

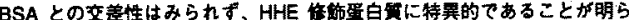
加となった。 His,CyEおよびLysのHHE付加体を用いて competitive ELISA

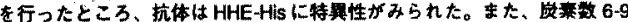
の-hydroxy-2-alkenal と His との付加体を用いて competitive ELLSA を行 ったところ、C8までを路誡することが判明した。

2Pp 18

異なる光㷌境下て生育したEuglena gracilis Z おょU゚SMZに

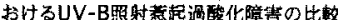

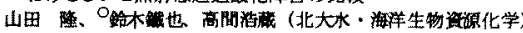

(目的) 我々は先に異なる光整境下て生育させたEuglena絊胞における

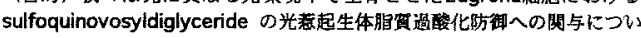

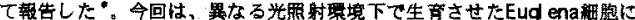

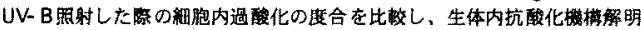

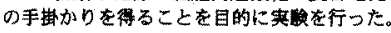

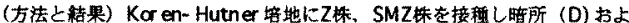

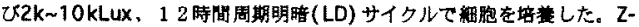

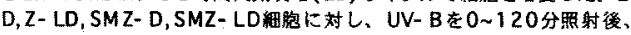
dichlorofluorescin-diacetateをprobeとするphotn countingによる細胞 内渦醴化. HPLCKよるTBARS, 8-OH-deoxyguanosine (8-OH-dG)， $\alpha$ -

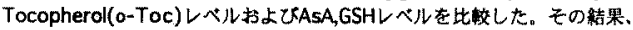

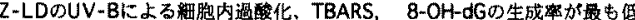
かった。また、 $\alpha$-Tocレべルは他の光樶射条件下て生育させたEug enaの そ扎と比敕してZ-LDが樰めて高く推移することが分かった。光合成能を

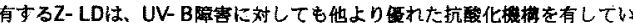
ることが䆩えた

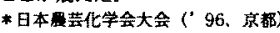

\section{Pp 19 Preparation of Lutein and Its Fatty Acid Esters}

${ }^{\circ}$ A. Subagio, N. Morita (Food Chem., Coll. Agric., Osaka Pref. Univ.)

Carotenoids are commonly used as food additives and antioxidants, and they are important as provitamin $\mathrm{A}$, and anticarcinogen. In plant, oxygenated carotenoids mostly exist as the ester form of fatty acid. However, at present only a few studies on carotenoids fatty acids ester were reported, because of difficulty of their preparation. In this study, we could easily prepare lutein which is a kind of oxygenated carotenoids and its fatty acid esters. Marigold flower was used as a source of lutein. Free lutein was purified with the combination of silica gel and reversed-phase liquid chromatography. Then it was esterified to fatty acid ester with fatty acid chloride in the presence of triethylamine. The free lutein, mono lutein and diester lutein were separated using silica gel, and further purified using reversed-phase liquid chromatography. The lutein and its fatty acid esters were identified by chemical tests, spectrophotometer, TLC, HPLC, GC and MS 
2Pp20

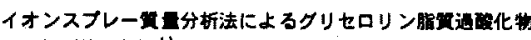
の分析 (第 2 㗉)

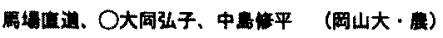

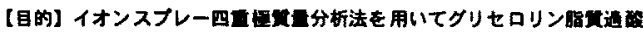
化物の分析を田みた。

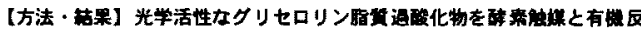
衿期合わせにより合成したこれら（ホスファチジルコリン、ホスフフ チジルクリセロール、ホスファチジエタノールアミン) $\mathrm{H}_{2} \mathrm{O} / \mathrm{CH}_{3} \mathrm{CN}(1: 1)$ (10ppm, +0.1\% TFA) とし、 イオン

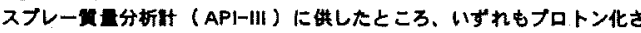

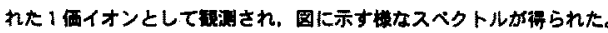

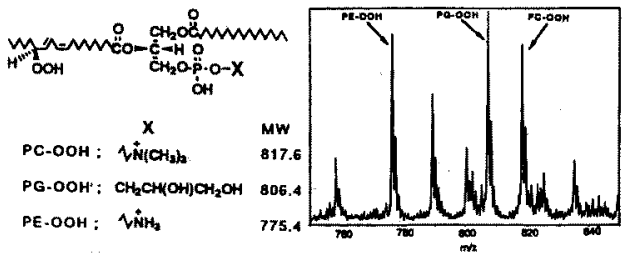

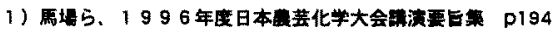

$2 P p 21$ 化学発光法による保存時におけるイカ肝䁍中の ヒドロベルオキシドの測定

近落 秦男 (東垔大工・食工)

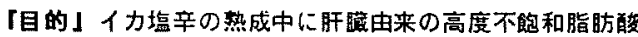
(PUFA)がとの程度酸化されるのかを調べるために、化学発光 (CL)法でヒトロベルオキシド(HPO)を測定すること試みた。 「方法と結果」食塩を10\%になるようにスルメイカの䀒䁍に 添加し、200で 10 日間保存した。この間、経日的にサンブリ ングレ Bligh \& Dyer 法で脂質を抽出した。CLの測定は CLA gystem (東北電子産業) で行い、発光試租は isoluminol/cyt c 系を用いた。比較のため、鉄一チオシアネート(FT)法・とT B A法でも HPOの測定を行った。CL法とFＴ法の険量線は，

リノール酸のリボキシゲナーゼ娃理生成物（13-LOOH）で作 成した。その結果、CL法でHPOを定量することが可能であ った。保存中に HPOは增加するが、多量の PUFA が存在す る朌にはその增加は軽微であり、保存中に増隇した。また、F 丁法でも同㥞の結果が得られた。

“市川和昭ら、日本油化学会誌、第 45 巻 $(4) 、 37 \sim 41$ (1996)

2Pp22 鞂したダイスオイルボテイに対するトリプンンの作用

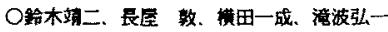

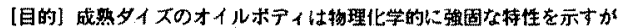
他方in viroて醉来の作用を受忛易く、べフシンあるいはリバーせにより 完全に破域される事は既に報告した。トリフシンの作用模式は視誰であ り、これを明らかにするために、トリフシンによるオイルホテイ表層夕

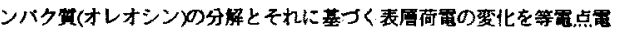

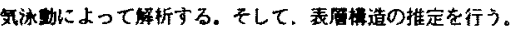

[結果] トリフシンによりオレオンンが部分分解され、低分子化するま

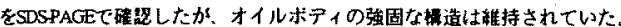

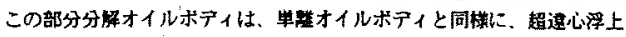
法によって回收可能であった。オイルボアイは直径0.5 2 $\mu \mathrm{m}$ の徐粒子て

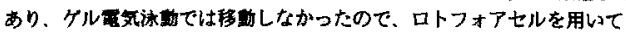

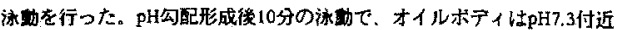

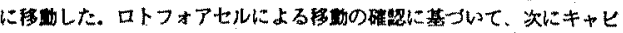

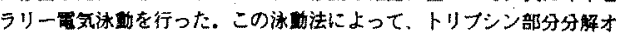

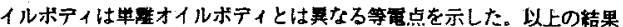

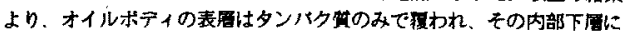

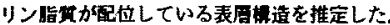

2Qp 1

$$
\begin{aligned}
& \text { HPLCによる萣品中のグルタチオン } \\
& \text { ペルオキシダーぜ活性の测定 }
\end{aligned}
$$

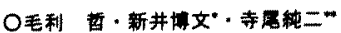

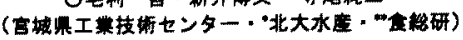

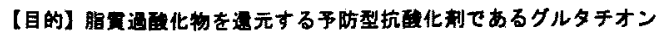

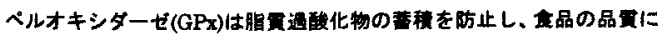

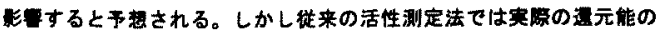

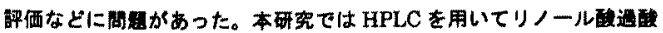

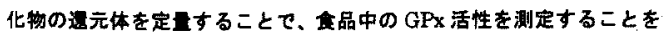
眐みた。

【方法】GPx 活性は、クルタチオンを和した策件下でー佷的な coupled enzymatic 法 (CE 法) および HPLC 法により测定した。HPLC

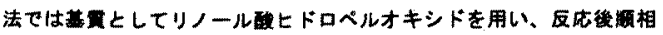
HPLC 上で通元ヒドロキシ体を定是し、遗元能を脬洒した。

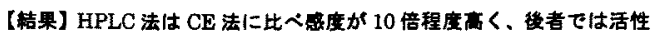

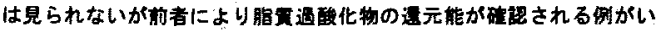
くつかあった。供蝴した品の中ではマグロが最も高いGPX 活性を示 した。一方万能杖は、CE 法では活性は現れないものの HPLC 法て

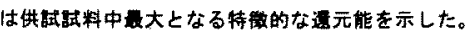

2Qp2 抗酸化作用をもつペプチドライブラリーの作成

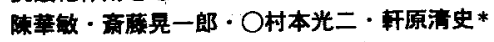

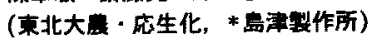

【目的】先に济者らは，大豆タンパク西の醇素分解物より6程 䫓の抗酸化ベプチドを単雃し、槽造を沠定した。これらは5か ら16牫基のアミノ酸からなり，いずれもHisあるいはTyrを含 む。本研究では，この中のLeu-Leu-Pro-His-Hisをリードと

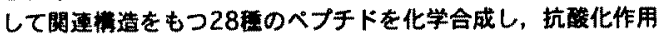
を比較すると共に，HisまたはTyrを2残基含むトリペブチドの ライフラリーを作成し，抗酸化作用を指標にスクリーニンクを 行った。

【方法と萿果】抗酸化作用は，水溶液柔におけるリノール酸の

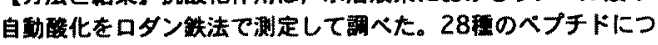
いて，抗藂化特性，金属キレート形成能，㻋水性度等を梌討し た結果，Pro-His-Hisに最も强い抗酸化性を見つけ，抗酸化作 用の発現にはHisの1次情造上の位置が曋要であることが分かっ た。また，114枉のトリペプチドから满成されたライブラリー のスクリーニンクによより、Tyrペプチドの模造活性相関に閣す る知見を得た。

2 Qp3

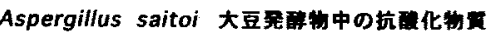

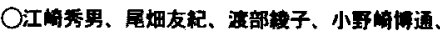

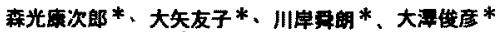
(相山女大・生科、*名大・異)

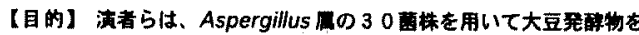

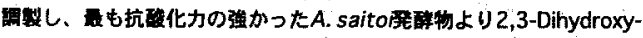

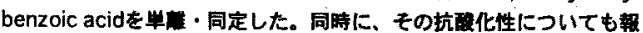
告した"。今回、同し大豆発醉物より新たな抗酸化成分を単篮し、こ

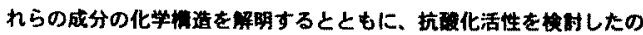
で靯告する。

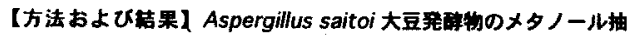
出物よりシリカゲルカラムおよひ ODS を用いた分取 HPLC を練り返

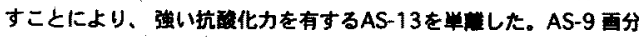
は、さらにToyopearl HW-40 クロマトダラフィーを行うことにより、

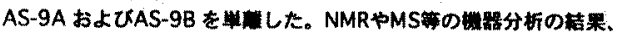
AS-9B、AS-13をそれそれ8-Hydroxygenistein、8-Hydroxydaidzein

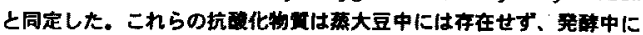

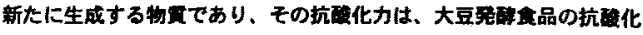

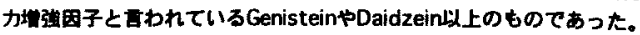

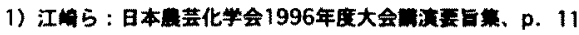


【目的】オオバナサルスベリ (Lagerstroemia speciosa L.) は、アジア地城に生息するミン八キ科の棝物であり、フィ リビンにおいて、この葉を照したものがバナバ莱として䣄 用されている。また、その機能性として血楉上昇抑制作用 を有することを報告した。そこで今回は、このバナバ葉熱 水抽出物の抗酸化作用について検討した。

【方法およひ結果】フィリピン産の乾燥バナバ葉を細かく

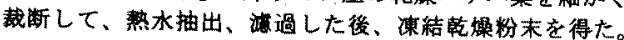
この㛺燥粉末の成分分析を行った結果、タンニンを約 37 \%含有していた。なお、カフェインは検出されなかった。 轨酸化試鋻として、1,1-diphenyl-2-picrylhydrazyl (DPPH) ラジカルの消去活性、リノール酸ーエタノール系での酸化 㧕制活性等で部価した。その結果、バナバ葉等水抽出物は

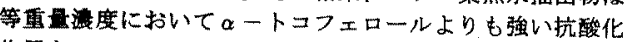
作用を示した。

2 Qp5 大根繁水抽出物の抗酸化活性

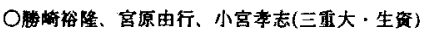

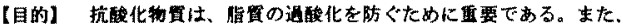

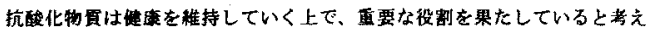

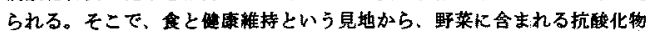

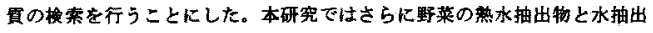

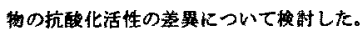

【方法・結果】数碑の野菜について䓡水抽出を行い、それそれれの抽出物 をりノール酸を基筫としたロダン铁法、TBA法により抗酸化活性を比輁し

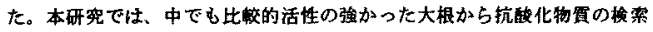
を行った。

大根を整水中で60分間抽出した。 XAD-2の樹脂を充填したオーブンカラ ムクロマトダラフイーに抽出物を供し、水・タタールの比率を变えて溶出 した。モ机らのうち、20\%MeOH面分が活性を有していた。その便分をさ

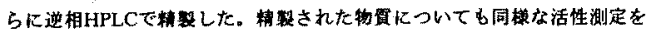
行ったところ、活性を有することが判った。これらの活性物留について模 造船析を行った。

また、大根の愁水抽出物と水抽出物について、抗酸化活性の比較を行っ た。これら抽出物を物䨘レベルがら榙討したところ、抗酸化活性に関する いくつかの知見が燔られた。

\section{Qp6 レモン柴実由来の抗酸化威分}

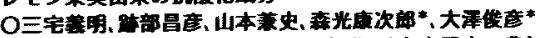

((妹)ボッカコーボレーション中础、“名古屋大・噹)

1.目的作年度の本大会で、レモン果实には抗酸化成分 Eriocirtin (Eriodictyol-7-o-rutinoside) 加多く含有し、

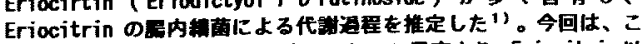

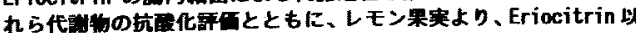

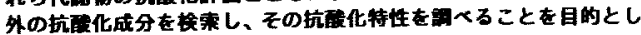
E。

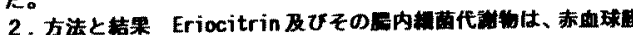

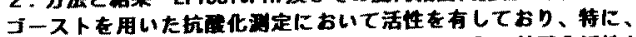
Eriocitrin のアクリコン部分である Eriodictyol に接霞化活惟が 高加ったレモン果実加らの摭酸化成分の策について、レモン果

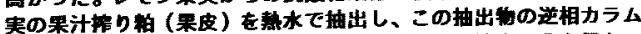

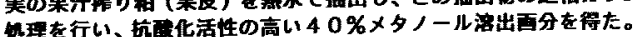

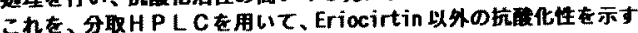

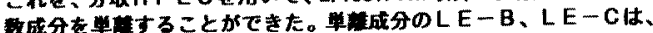
器分析 (MS、'H-、 ${ }^{13} \mathrm{C}-\mathrm{MNR}$ ) 结果より、C-クリコシルフ ラボン疑であると推定した。また、HPLC分析により、

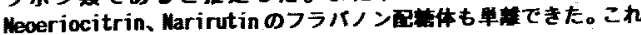

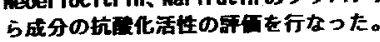

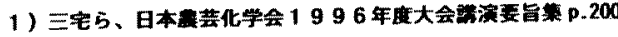

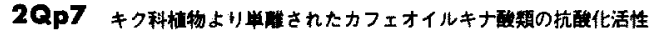

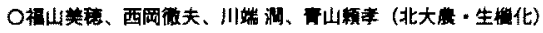

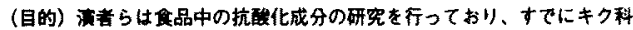

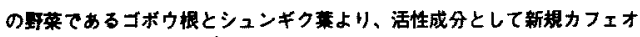

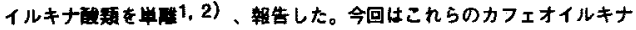

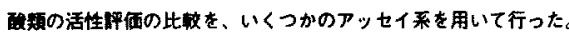

(方法およひ蛣果) シュンキク (Chrvsanthemum coronalium) とコボ

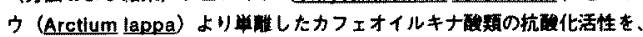
リポソーム、リノール酸-SDSミセルを用いて湘定した。リポソームは明罢 ホスファチジルコリンを用いて超音波処理により作成した。リポソーム、

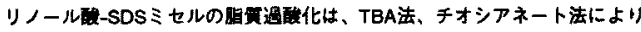
则定した。カフェオイルキナ諎は、ボジティブコントロールとして用いた

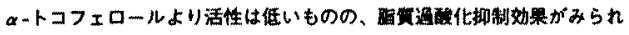

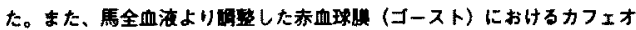

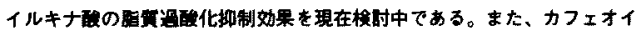

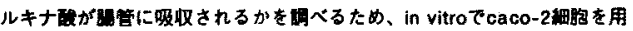
いて今䋇模期を行う予定である。

1) Y.Maruta, J.Kawabata and R.Niki, J. Agric. Food Chom., 43, 2592 (1995)

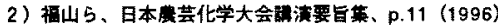

2Qp8

$$
\begin{aligned}
& \text { ローズマリー、ターメリックおよびカブシカム色素 } \\
& \text { のマウス体内での抗酸化刹果について }
\end{aligned}
$$

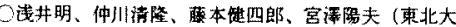

$$
\begin{aligned}
& \text { 農・店生化) }
\end{aligned}
$$

【目的】抗酸化作用の期待される食品添加物の生体内での奻果を 明らかにするために、ここでは、ロースマり一抽出物、ターメ リック抽出物（99\%クルクミン）拉よびカブシカム（唐辛子）色 菜の抽出物をマウスに投与し、生体膜りン脂質の過酸化に与文る

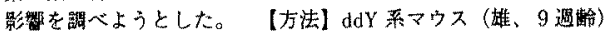

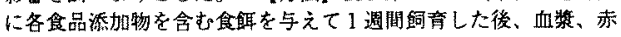
血球および肝瞒の過酸化りン脂犋量をCL-HPLC法で測定し、添加 物を与えなかった对照マウスとの比挍を行った。【結果】りン 脂留ハイドロハーオキサイト (PLOOH) の鱼は、対照マウスと比 較して、各添加物を与えた群で、とくに赤血球膜において60ー

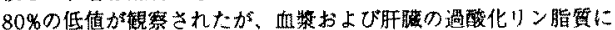
は有意な羙は認められなかった。この結果は、私たちが以前行っ たß゙カロチンの堨合と同しであった。また、ローズマリ一抽出物 を与えたマウスでは、肝䁦の $\alpha$ トコフェロールが低值であった。 •K. Nakagawa, et ad. : Biochim. Biophys. Acta.. 1299.110116 (1996).

2Qp9 植物フラポノイトによる血柀の抗酸化性の変化 O下位香代子、市讧恭子、岡田寿讧、木苗直湾 (静岡県大·食品栄蓄科学)

【目的】植物フラボノイドの血整衼强作用は、以前より知られて

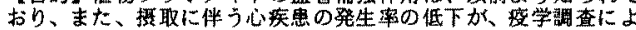

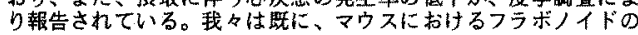
生体内抗酸化性を報告しだ 2\%。今回、ヒトの血管内酸化ストレス に对するフラボノイドの抗化珄を明らかにすることを目的とし て、植物性食品㨨取後のフラボノイドの血中濃度の湘定結果をも とに、血液の抗酸化泩の変化をラジカル発生㓩を用いて、Comet assay(single cell gel assay) $\downarrow \downarrow \mho U$ ORAC assay(oxygen radical absorption capacity assay)により㛟討した。

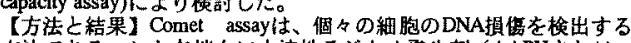
方法である。七ト末梢血に水溶性ラシカル発生削 (AAPHまたはつ エントン試薬)および各フラボノイド(ケルセチン、ルテオり

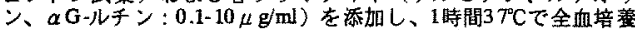
㷋、DNA損煷度を比へたところ、フラボうイド存在下の方か、㨁

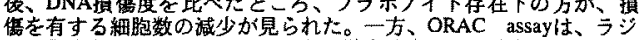
为儿発生剂による $\beta$-phycoerythinの䖝光㤝度の低下を指摽にし 血清の抗酸化性を調へる方法である。血清は、種々の抗酷化物晢 を含习、抗酸化性を有するか、血清に各フラボノイドを添加する と、さらに強い抗醊化性汃見られた。以上の結果は、体内に吸收 されたフラボノイドが、血管内で抗酸化性を発揮しうることを示 战するものであった。

1) Carcinogenesis,15,2669(1994) , 2) Mutat.Res.,350,153(1996) 


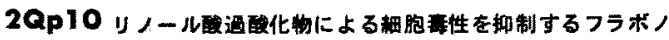
イト.

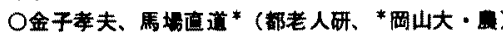

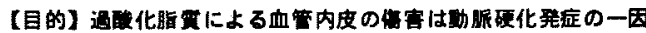

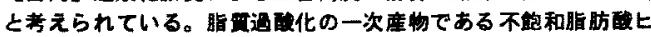

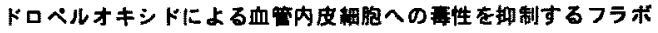
ノイドの検䨛を行った。

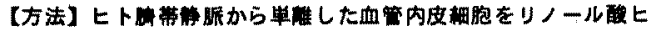
トロベルオキシトで処理した。フラボン、フラボノール、フラハ ノンなどのフラボノイドをヒドベルオキシドと同時に培地に杀

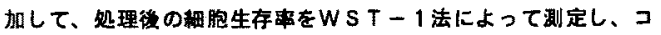
ントロールと比して、それらの等性抑制勃果を铎べた。

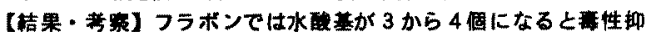
制作用が現れ、特にルテオリンが作用を示した。3位に水聠 基を持つフラボノール類はいずれも蝴制作用を示したが、特に水 酸基が3から5 個のガランギン、ケルセテンなどが強い効果を示 した。フラバノンやインフラボンの効果は弱かった。ヒドロベル

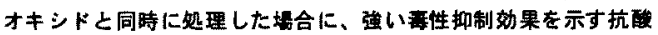
化性化合物が少ないので、これらフラポノイドは注目される。

2Qp1 1 モデルワイン容液に拐けるボリフェノール類の化学的変化

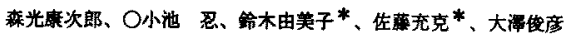
(名大展 结用生物、*メルシャン蓄整研)

【目的】 French paradox寄与している物置を化学的に解析する目的て、

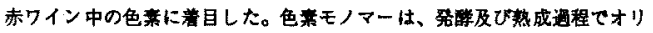
コマーやボリマーに交化することが知られている。そこて本研究ては、モ アルワイン溶湤中に゙いて、ホ、リフェノール類の分子レベルにおける化学 的艾化と機能の解析を行った。

【方法と結果】ワイン瞵をいて、用いイン中の成分でる

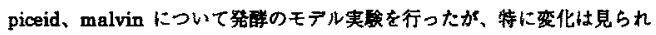
なかった。ワインの算成とともに、アントシアニンモノマーがアルデヒト

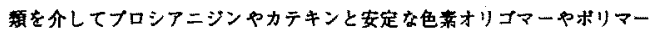
を形成すると考文られている。そこで、ブウ果皮から分取したアントシ アニン(malvidin 3-glucoside) $と(-)$-picatechin、acetaldehydeを含むモ ルワイン浩液の絽陆変化をHPLC分析したところ、付加反応物と思われる

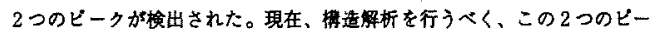

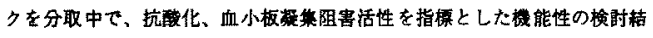
果做世て報告する。

2Qp12 ワイルドライス中のフェノール性抗酸化物貫の權造と譏能

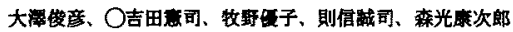
(名大震・束用生物)

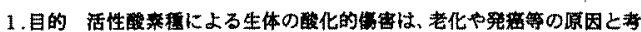
えられている。これまで、アメリカインディアンの伝統的搉物でるワ

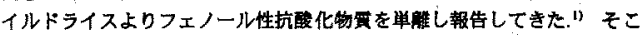

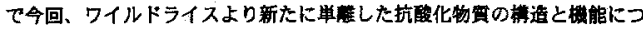
いて報告する。

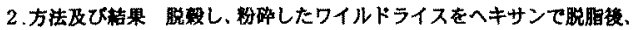

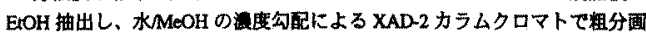
した。各面分の抗酸化活性をロダン铁法、キサンチン・キサンチンオキシ ダーゼ法等て明へたところ、20\%、40\%、60\% MeOH frs.に强い抗酸 化活性が見られたので HPLC を用いて㜔酸化物貫を単解した。6 $0 \% \mathrm{MeOH}$

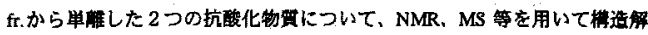
析を行った結果、アヒダニン骨格の 6 位と8位にアラビノースがヘ・グリコ シト結合した 6,8-di-C-arabinopyranosylapigenin と、6 位または 8 位にアラビ ノース及びダルコースが結合した 6(8)-C-arabinopyranosyl-8(6)-C glucopyranosylapigeain と推定した。これら $2 つ の$ 化合物は㧧い $\mathrm{OH}$ ラジカ ル掅捉能を有していたのて、現在 $20 \% 、 60 \% \mathrm{MeOH}$ frs.より單離した抗破化

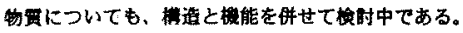

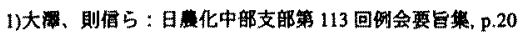

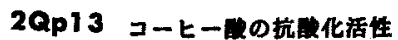

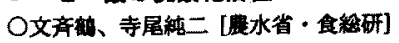

【目的】植物性食品に広〈存在する抗酷化性成分でるコーヒー 酸 (3,4-dihydroxycinnamic acid)に注目し、その抗臤化機槽を明ら かにすることを目的とした。

【方法・結果】コーヒ一能と安定ラジル DPPH (2,2-diphenyl1-picrylhydrazyl) との反応において、システインを基率にすると コーヒ一酸は約 6 分子の DPPH ラジカルを捕捉することが示さ れた。また、ラードの自䡃酸化に対するコーヒー酸の抗酸化活

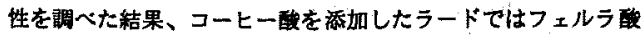
および $\alpha$-Toc 添加ラードよりもそれぞれ約 4 倍 およひ 2 倍楼導 期が延長された。さらに、水溶性およU脂溶性ラジカル発生剂 (AAPH, AMVN) や铁イオン触某によるモテル油脂 (リノール競

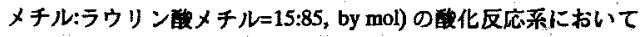

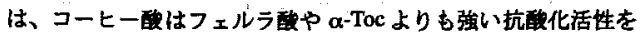
示した。特に、饦イオ螌媒で著しい奻果加見られた。現在、 モテル油脂におけるコーヒー酸の反店生成物の分析により詳し い反応機構を检狽している。

2Qp 14 gallic acid エステルの生体内脂需過酸化揤制作用 ○石川昨芙，本田焦，原口十尃行，神川忠男・，久保伊佐夫"

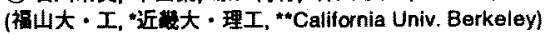

[目的] gallic acid 及びそのmethyl, propyl, laulyl エステルは抗化化作

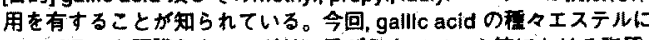
ついてラット旰墔ミトコンドリア及びミクロソーム等における脂監 過酸化抑制作用などについて楼期を加えた。

[方法・結果]王スデルの一新(n-hexyl, n-octyl, n-decyl, n-tetradecyl,

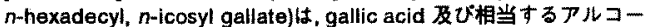

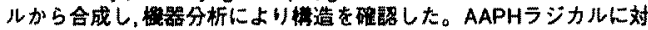
する除去作用は、すべてのエステルにおいて同等の作用を示した。

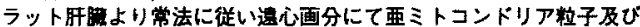

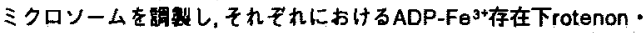
NADH 传存性過腹化脂算またはNADPH-P-450 reductase 依存性通 酸化睧虽の生成を測定したところ, hexyl, octyl, decanyl, 及び dodecanyl ester に抑制奻果が棓められた。これらより档長の長いも のに対しては抗酳化作用は略められず，特にミトコンドリアにおいて は鎖長の短いエステルも無奻であった。一方, xanthine-XOD系によ るスーバーオキサイドアニオンに対しては綃長の短いエステルほと

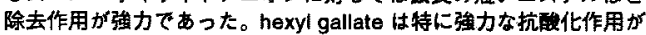

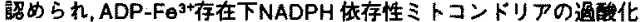
における cytochrome reductase 活性の低下及び. AAPHラジカルに

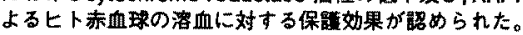

2Qp 15 SODによるユどキノール $\left(\mathrm{COQ}_{0} \mathrm{H}_{2}\right)$ 酸化の排

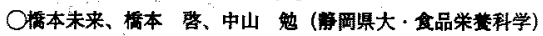

く目的〉ユどキノールの酸化にスーバーオキシドか間与することが考え られているが、実雅的な赛付けはなされていない。をこで本研究で、

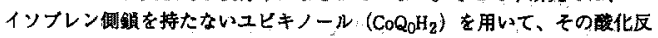

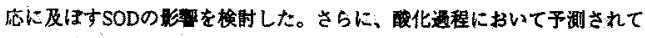

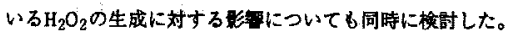

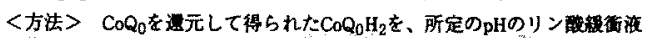

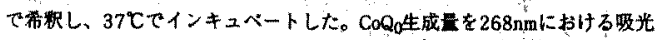
度台求め、同時に生成す $る \mathrm{H}_{2} \mathrm{O}_{2}$ 至をphydroxyphenylacetic acidの取化反 応によって濑定した。

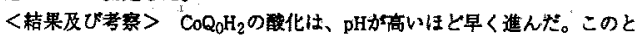
き生成する $\mathrm{COQ}_{0} と \mathrm{H}_{2} \mathrm{O}_{2}$ の量柱忹等しかった。 SODを加えることによりわ

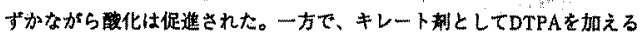
と $\mathrm{COQ}_{0}$ と $\mathrm{H}_{2} \mathrm{O}_{2}$ の生成量はともに半分程度々排えられた。この策件下に扫

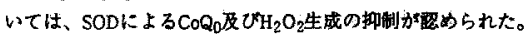

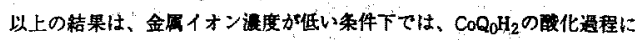
スーバーオキシドか跑与していることを示唆している。 